\title{
Pendidikan Formal Era Hindia Belanda di Kepulauan Sangihe Pada tahun 1848 - 1945
}

\author{
Oleh : Veronika Horohiung \\ Pendidikan Sejarah PPS UNJ
}

\begin{abstract}
This research is a historical with the problem's focus in how the development of formal education at Sangihe Island in the end of era XIX century and early XX century. The purpose of this research to use in historic method. Spesifically for Sangihe Island the purpose of build and education institute by Netherland especially not for the impotance of Indonesian people in common but special for Sangihe people actually for the Indonesia people that is it fill low position in government and to fill the manpower of company so that in the future the programs of education in Indonesia will more important orientation of society. Not just political importence
\end{abstract}

Keyword: education, influece, Netherland, Sangihe island

\begin{abstract}
Abstrak
Penelitian ini adalah penelitian sejarah dengan fokus permasalahan bagaimana perkembangan pendidikan formal di Kepulauan Sangihe dalam kurun waktu akhir abad XIX dan awal abad XX dan penelitian ini bertujuan untuk menjelaskan perkembangan pendidikan formal di Kepulauan Sangihe. Metode yang digunakan adalah metode historis, teknik pengumpulan data yaitu kajian pustaka, dan waktu penelitian November 2013 - Juni 2014 tempat penelitian adalah perpustakaan. Khusus untuk kepulauan Sangihe tujuan mendirikan lembaga pendidikan oleh Belanda terutama bukan untuk kepentingan orang Indonesia pada umumnya terlebih khusus orang Sangihe, tetapi sesungguhnya adalah untuk kepentingan mereka, yaitu mengisi jabatan rendah dalam pemerintahan dan untuk mengisi tenaga pada perusahaan swasta Belanda. Seyogyanya program-program pendidikan yang di Indonesia, hendaknya lebih berorientasi pada kepentingan masyarakat dan bukan kepentingan politik
\end{abstract}

Kata Kunci: Belanda, kepulauan Sangihe, pendidikan, pengaruh

\section{PENDAHULUAN}

Indonesia adalah sebuah gugusan kepulauan yang sangat besar dan memiliki letak strategis karena berada pada posisi silang antara dua benua, Asia dan Australia dan dua samudera yakni Samudera Pasifik dan Samudera Hindia, disertai kekayaan melimpah, telah menimbulkan niat bangsa-bangsa asing untuk menguasainya.

Pada abad XVI dan XVII masuklah bangsa-bangsa asing ke Indonesia, seperti Portugis, Spanyol dan Belanda dan merupakan penetrasi Eropa dalam bentuk kekuasaan kolonialisme, sehingga
Indonesia pun menjadi negeri yang terjajah. Kedatangan bangsa-bangsa ini pada awalnya mereka menyebarkan agama dan ideologi penjajahan kemudian mengembangkan sistem pendidikan. Sebelum Indonesia dijajah oleh bangsa lain, bangsa Indonesia telah memiliki tradisi pendidikan sendiri yang dikelola oleh masyarakat atau komunitas yang dipengaruhi oleh adat istiadat, tradisi, budaya, agama dan kepercayaan masingmasing.

Sebagai gambaran bahwa pendidikan di kalangan masyarakat Sulawesi Utara 
dilakukan dalam bentuk penyerahan pengetahuan dan keterampilan dari orang tua kepada anak-anaknya. Khusus bagi Kepulauan Sangihe Talaud masyarakat juga menganut kepercayaan animisme dan terikat dengan aturan adat-istiadat yang diajarkan secara turuntemurun. Pemimpin upacara keagamaan (kepercayaan animisme) biasa disebut Ampuang. Mereka ini adalah orang tua yang memiliki banyak ilmu pengetahuan tradisional dan sebagai dukun besar yang dapat mengobati orang sakit, menolak bala dan lain-lain.

Kemudian yang dimaksudkan dengan pendidikan tradisional adalah merupakan sarana untuk mewariskan dan menurunkan nilai-nilai budaya. Pendidikan ini adalah pendidikan informal di mana orang tua maupun anggota keluarga lainnya berusaha mendidik anak-anak mereka dengan terampil mengerjakan pekerjaan seharihari di lingkungan keluarga. Tujuannya adalah mempersiapkan anaknya mampu hidup mandiri berdasarkan kekuatan sendiri sampai mereka dewasa dan hidup berumah tangga.

Sebelum Portugis dan dengan Spanyol masuk di Kepulauan Sangihe Talaud misi Katolik, sebagian masyarakat sudah menganut agama Islam (Islam Tua). Akan tetapi pengajaran agama ini, dilakukan secara lisan atau disampaikan dari mulut ke mulut (secara hafalan) dari generasi ke generasi. Pendidikan agama ini tidak dapat dikategorikan dalam pendidikan formal. Agama Katolik pun diterima dengan senang hati oleh masyarakat Sangihe Talaud yang dibawa oleh pelaut-pelaut Portugis dan Spanyol yang banyak singgah di kepulauan ini.

Adapun tujuan pelayaran bangsa barat adalah untuk mencari daerah-daerah baru dengan membawa misi agama dan perdagangan. Misi mereka dapat berjalan dengan baik karena penduduk setempat diberi pelajaran tentang pengenalan huruf sampai dengan membaca dan menulis.

Pada zaman pemerintahan Hindia Belanda, pendidikan sudah mulai diperkenalkan walaupun masih terbatas pada kalangan tertentu saja. Namun secara berangsur-angsur dibangunlah gedung-gedung sekolah dasar di berbagai pelosok wilayah Hindia Belanda sehingga pendidikan itu dapat dinikmati oleh penduduk pribumi..Pengaruhkebudayaan Eropa ke dalam kebudayaan Indonesia yang bersifat positif, wujudnya antara lain perkembangan sistem pendidikan sekolah-sekolah Belanda, lewat penerapan ilmu pengetahuan dan teknologi dalam kehidupan orang Indonesia. Kehadiran bangsa Belanda dengan misi yang sama juga membawa serta ilmu pengetahuan, sehingga penduduk Kepulauan Sangihe Talaud dapat menikmati pendidikan formal di gedung sekolah.

Pelaksanaan sistem pendidikan pada masa pemerintahan kolonial Belanda didasarkan pada sistem a colour line devision (perbedaan garis warna). Pelaksanaan pendidikan seperti ini menimbulkan begitu banyak reaksi dari masyarakat, karena adanya diskriminasi pemberian pendidikan bagi masyarakat.

Diskriminasi pendidikan tentunya berdampak luas di kalangan masyarakat. Bagi masyarakat yang berasal dari kaum bangsawan, pendidikan tidak menjadi persoalan, karena masyarakat golongan bangsawan dapat dengan mudah mengenyam pendidikan. Tetapi bagi masyarakat di luar kelas sosial tersebut (masyarakat bawah) walaupun secara intelektual mampu, tetap tidak bisa mengenyam pendidikan seperti golongan 
bangsawan. Hal ini berarti perbedaan diciptakan oleh kaum kolonial dalam masyarakat Indonesia, dimana bahasa pengantar yang digunakan di sekolah bagi golongan bangsawan adalah bahwa Belanda, sedangkan bahasa pengantar bagi sekolah untuk golongan masyarakat biasa adalah bahasa Melayu.

Penggolongan pendidikan seperti ini, menunjukkan bahwa semakin kecil kesempatan bagi masyarakat pribumi untuk mengenyam pendidikan bersamasama dengan kaum bangsawan, hal ini semakin mempertegas diskriminasi dalam aspek pendidikan yang dilakukan oleh pemerintahan kolonial Belanda di Indonesia.

Sistem pendidikan pada masa ini, pada umumnya dianggap sebagai alat untuk menyeleksi dan melatih orang Indonesia untuk memegang status dalam masyarakat. Sistem pendidikan yang dijalankan oleh pemerintah Hindia Belanda menyebabkan muncul reaksi dari kaum pergerakan nasional. Untuk mengimbangi sekolah-sekolah buatan Belanda, maka kaum nasionalis mendirikan sekolah-sekolah untuk masyarakat, seperti di antaranya adalah Taman Siswa yang didirikan pada tanggal 3 Juli 1922.

Perkembangan pengajaran dengan sistem sekolahnya mau tidak mau disesuaikan dengan sifat dualistik masyarakat Indonesia, baik mengenai bahasa pengantarnya maupun sistem pelajarannya. Oleh karena itu, terdapat empat kategori sekolah yakni : (1) sekolah Eropa yang sepenuhnya memakai model sekolah Negeri Belanda; (2) sekolah untuk pribumi yang memakai bahasa Belanda sebagai bahasa pengantar; (3) sekolah bagi masyarakat pribumi yang memakai bahasa daerah/pribumi sebagai bahasa pengantar; (4) sekolah yang memakai sistem pribumi.

Melihat perkembangan pendidikan yang terjadi di Indonesia, pemerintah kolonial Belanda mulai memberikan perhatian terhadap pendidikan dan ini terlihat pada penerapan Politik Ethis (politik balas budi). Apapun perbedaan-perbedaan yang terdapat di antara mereka, pada prinsipnya mereka bersepakat, bahwa tanah jajahan memang seharusnya memberikan keuntungan bagi negara induk. Persoalan yang menjadi dasar percekcokan di kalangan politik kolonial adalah "bagaimana caranya mengeksploitasi tanah jajahan". ukan eksploitasi kolonial melainkan pertanggungjawaban moral.

Di luar perdebatan-perdebatan itu, muncul gerakan perbaikan dari golongan "ethis", nama yang kemudian dipakai untuk menyebut politik kolonial yang baru yaitu "politik ethis". Sistem politik baru ini merupakan ide dari salah satu juru bicara kaum ethis yakni Van Deventer yang menulis sebuah artikel dengan judul Hutang Budi.

Dengan demikian dipahami bahwa pendidikan adalah suatu proses atau upaya untuk mendewasakan, memajukan budi pekerti, dan pembentukan kepribadian seseorang ke arah yang lebih baik. Dalam suatu bangsa pendidikan mempunyai peranan yang sangat penting karena pendidikan merupakan suatu penentu untuk dapat maju dan bersaing dengan negara-negara yang lain. Sumber daya yang berkualitas bersumber dari pendidikan yang bermutu.

Sejarah mencatat bahwa kebudayaan asing yang disebut juga budaya luar cukup berpengaruh terhadap pendidikan di Indonesia. Kebudayaan itu masuk di I 
Indonesia di mulai dari kedatangan budaya Hindu, Budha, Islam kemudian disusul dengan budaya Eropa yang kesemuanya itu memberi andil bagi perkembangan budaya dan pendidikan di Indonesia termasuk di Kepulauan Sangihe. Oleh karenanya penelitian skripsi ini diberi judul "Pengaruh Belanda Di Kepulauan Sangihe" dengan penjelasan bahwa pengaruh Belanda secara luas kurun waktu tersebut mencakup berbagai aspek kehidupan di masa pemerintahan Belanda pada dasarnya menjalankan pendidikan berjenjang bagi masyarakat Indonesia sesuai dengan politik penjajahannya.

Identifikasi Masalah

Berdasarkan latar belakang masalah di atas, maka masalah-masalah yang muncul dapat diidentifikasi sebagai berikut :

1. Pengaruh kebudayaan bangsa barat terhadap kepercayaan dan adat istiadat lokal Kepulauan Sangihe

2. Pengaruh perkembangan misi keagamaan bangsa Belanda di Kepulauan Sangihe

3. Kurangnya perkembangan ilmu pengetahuan dan sekolah formal di Kepulauan Sangihe

Perumusan Masalah

Permasalahan penelitian ini dirumuskan sebagai berikut :

1. Bagaimana pengaruh Belanda dalam perkembangan pendidikan di Indonesia akhir abad XIX dan awal abad XX ?

2. Bagaimana perkembangan pendidikan masa akhir Hindia Belanda akhir abad XIX dan awal abad XX?

3. Bagaimana perkembangan pendidikan formal di Kepulauan Sangihe dalam kurun waktu akhir abad XIX dan awal abad XX
$? \backslash$

Tujuan Penelitian

Adapun tujuan dari penelitian ini yaitu :

1. Menjelaskan pengaruh Belanda dalam perkembangan pendidikan di Indonesia akhir abad XIX dan awal abad XX.

2. Menganalisis perkembangan pendidikan masa akhir Hindia Belanda akhir abad XIX dan awal abad XX

3. Menjelaskan perkembangan pendidikan formal di Kepulauan Sangihe dalam kurun waktu akhir abad XIX dan awal abad XX.

\section{METODE PENELITIAN}

Tempat berlangsungnya penelitian ini adalah perpustakaan sedangkan waktu yang digunakan dalam penelitian ini adalah 8 (delapan) bulan yaitu terhitung dari bulan November 2013 sampai dengan bulan Juni 2014 dengan tahap-tahap kegiatan sebagai berikut:

a. Tahap pertama dan bulan November Desember 2013. Kegiatan yang dilakukan dalam tahap ini adalah pengumpulan bahan berupa literatur yang berkaitan dengan permasalahan penelitian dalam rangka penyusunan proposal untuk diseminarkan.

b. TahapkeduadaribulanJanuari-Juni 2014. Dalam tahap ini kegiatan yang dilakukan adalah pengumpulan sumber, pengolahan data dan analisis serta penulisan laporan hasil telitian dalam bentuk skripsi dan pembimbingan. Kegiatan berikutnya adalah pengajuan konsep skripsi untuk diperiksa pembimbing, perbaikan konsep berdasarkan catatan pembimbing dan pengusulan untuk persetujuan pembimbing guna pemantapan sebelum diajukan dalam ujian komprehensif. 
Dengan penggunaan metode sejarah diusahakan untuk mengemukakan data. Bertolak dan sumber data penelitian, realita dalam pelaksanaan penelitian ini maka ditentukan sumber data yang digunakan adalah data sekunder, yaitu bahan-bahan tertulis tentang sejarah pendidikan di Indonesia Kepulauan Sangihe dalam kurun waktu akhir abad XIX dan awal abad XX.

Bertolak dan sumber data penelitian sejarah di atas, dan realita dalam pelaksanaan penelitian ini maka ditentukan sumber data yang digunakan adalah data sekunder, yaitu bahan-bahan tertulis tentang pokok permasalahan yang diteliti.

Pengumpulan data dalam penelitian ini digunakan "kaji pustaka" yaitu mendalami, mencermati, menelaah dan mengidentifikasikan hal-hal yang telah ada untuk mengetahui apa yang ada dan yang belum ada. Sehubungan dengan sumber data yang ditentukan dan digunakan dalam penelitian ini adalah sumber-sumber data sekunder, maka bahan yang dikaji meliputi buku dan laporan hasil-hasil penelitian yang telah dilakukan terdahulu.

Data yang berhasil dikumpulkan dengan teknik kajian pustaka, selanjutnya dianalisis dengan menggunakan teknik kritik sejarah.

\section{HASIL PENELITIAN DAN PEMBAHASAN}

Pengaruh Belanda Dalam Perkembangan Pendidikan Di Indonesia Akhir Abad XIX dan Awal Abad XX

Harus diakui bahwa perkembangan pendidikan pada masa kolonial Belanda diawali dari pulau Jawa. Hal ini bukan berarti perkembangan pendidikan di luar pulau Jawa tidak jalan. Perkembangan pendidikan di pulau Jawa pada masa kolonial Belanda dimulai sejak tahun 1840-an, yakni sejak didirikannya sekolah gubernemen. Menurut rencana setiap keresidenan akan didirikan sekolah pribumi bagi anak-anak pegawai serta orang-orang terkemuka. Residen dengan bantuan Asisten Residen, kontrolir atau bupati bertanggung jawab atas segala urusan sekolah itu, termasuk anggaran belanjanya.

Untuk menyiapkan tenaga pengajarnya di Sala dibuka sekolah guru pada tahun 1852. Dengan memegang standar tinggi dalam pendidikan mereka akan mendapat posisi sosial yang cukup tinggi. Mereka sebagai elit intelektual dapat mempunyai pengaruh yang baik kepada masyarakat luas di luar sekolah. Sehubungan dengan tujuan pendidikan guru itu, maka dipilih Sala sebagai tempat di mana sekolah tersebut didirikan.

Sala di mata masyarakat umum Jawa sebagai salah satu pusat kebudayaan atau peradaban Jawa (kejawen), bahasa yang digunakan adalah bahasa Jawa standar. Kedua alasan tersebut yang menjadi pertimbangan Belanda untuk memilih Sala dan bukan Magelang atau Semarang sebagai pusat pendidikan guru.. Perlu ditambahkan pula bahwa di Sala, masih terdapat semacam pusat studi bahasa Jawa di mana para sarjana melakukan studinya, seperti Wilkens, Winter, Mounier, Gericke, dan Cohen Stuart.

Tenaga para sarjana ini dapat dipekerjakan untuk menyusun bukubuku sekolah. Terlepas dari tujuan pemilihan salah sebagai pusat sekolah guru, terdapat sebuah hambatan dalam sistem pengajaran di Sala yaitu segala kegiatan akademik harus dilakukan dengan menggunakan bahasa Jawa. 
Pendidikan guru yang berkembang pada saat itu memakai sistem asrama sehingga para siswa agak terisolir dari masyarakat pada umumnya serta disiplin ditanamkan secara sunguh-sungguh ditambah dengan pola hidup sederana yang diterapkan.

Sebenarnya pada awalnya terdapat kebijakan Belanda berkaitan dengan penerimaan siswa yang lebih diperioritas kepada anak-anak dengan keturunan kebangsawanan, namun pada praktiknya kebijakan itu tidak berjalan dengan baik. Salah satu penyebabnya adalah bahwa dari pihak bangsawan ada keengganan masuk sekolah guru karena disiplinnya sangat keras. Setelah berjalan sepuluh tahun lebih, maka terasa ada kebutuhan Belanda untuk menggunakan tenaga pribumi dalam pengajaran bahasa Belanda.

Berikut terdapat empat kecenderungan perkembangan pendidikan di Indonesia akhir abad XIX, yaitu :

1. Sesuai dengan aliran liberalisme yang masih sangatkuat pengaruhnya di Belanda, pendidikan yang diselenggarakan oleh gubernemen harus bersifat netral, artinya tidak didasarkan atas aliran agama tertentu, maka mata pelajaran agama tidak diberikan

2. Politik bahasa yang ditempuh juga lebih memperhatikan prinsip kebudayaan dan kesukarelaan, yaitu dalam pelajaran bahasa Belanda dalam menanggapi minat besar di kalangan pribumi, terutama di lingkungan aritokrasi, lebih jelas rasa keengganannya untuk memasukan bahasa Belanda dalam kurikulum sekolah

3. Sejak semula pembukaan sekolahsekolah lebih didorong oleh kebutuhan praktis yang berhubungan dengan pekerjaan di berbagai bidang atau di berbagai instansi baik pemerintah maupun swasta yang ada di Indonesia pada saat itu
4. Ada gagasan kuat agar sekolah pribumi lebih berakar pada lingkungan kebudayaan sendiri, maka bahasa pengantar yang digunakan adalah bahasa daerah masing-masing.

Sama halnya dengan di pulau Jawa, perkembangan pendidikan di luar pulau Jawa ditandai dengan pembukaan sekolahsekolah keguruan yang merupakan kebijakan dari pemerintah kolonial Belanda.

Masalah penyelenggaraan pelajaran bahasa Belanda telah ramai dibicarakan di tahun 1860-an. Sebelumnya ada pihakpihak yang menentang keras karena dipandang berbahaya jika masyarakat pribumi mengerti bahasa Belanda. Sementara itu di pihak lain, terdapat kelompok-kelompok masyarakat tertentu yang melihat manfaat dari pelajaran bahasa Belanda akan memudahkan penyampaian ajaran agama Kristen. Ada pula yang mengatakan bahwa kaum militer pribumi Ambon dan Manado, perlu diberikan pelajaran itu sebagai hak istimewa mereka.

Dalam perkembangan pemerintahan kolonial di tahun 1870-an, telah tumbuh dan berkembang sekolah-sekolah kejuruan karena masyarakat Indonesia pada saat itu lebih memerlukan tenagatenaga kejuruan. Pada tahun 1878, secara serentak dibuka hoofdenschool di Bandung, Magelang dan Probolnggo, serta Tondano. Di samping sekolahsekolah guru yang lama di Sala, Bandung, Fort de Kock dan Tanah Batu, juga dibuka sekolah-sekolah guru baru di Tondano (1873), Ambon (1874), Probolinggo (1875), Banjarmasin (1875), Makassar (1876) dan Padang Sidempuan (1879).

Perkembangan berikutnya, dalam penyusunan sistem pendidikan dan 
pengajaran di Indonesia paroh kedua abad ke-19, pemerintah Belanda tidak hanya mempersoalkan pengajaran umum dan kejuruan, tetapi masalah pendidikan elitis dan kerakyatan. Kecenderungan seperti ini sejak awal telah menunjukkan sifat elitisnya, sedangkan masalah pendidikan kerakyatan yang mencakup seluruh lapisan masyarakat, tidak dapat dipecahkan.

Sistem pendidikan dualistik ini secara tegas membuat garis pemisah antara subsistem, yakni sistem sekolah Eropa dan sistem sekolah pribumi. Berdasarkan sistem dualistik itu, maka untuk memenuhi kebutuhan yang semakin besar mempelajari bahasa Belanda, diciptakan sekolah khusus seperti pada uraian di atas.

Perlu diingat kembali, bahwa memasuki abad XX muncul golongangolongan politik yang mengeluhkan dan mengkritik politik kolonial yang berlaku pada waktu itu. Apapun perbedan-perbedaan yang lahir dari keluhan-keluhan tersebut, tetapi pada prinsipnya tanah jajahan harus memberi keuntungan bagi negara induk. Salah satu aspek yang menyebabkan terjadinya perdebatan-perdebatan tersebut adalah "politik keuangan" yang dijadikan slogan baru untuk memaksakan lahirnya suatu kebijakan pemerintahan kolonial terhadap kehidupan masyarakat pribumi.

Adalah kelompok liberal yang merupakan bagian dari politik kolonial yangkurangmemperhatikankesejahteraan masyarakat pribumi dilemparkan kritik terutama berkaitan dengan kemunduran kesejahteraan masyarakat pribumi pada akhir abad ke-19. Di antara para pengkritik itu, yang terpenting berasal dari C.Th van Deventer dengan judul Een Ereshuld (suatu Hutang Budi) yang kemudian dimuat dalam majalah de Gids pada tahun 1899. Bangsa Belanda sebagai bangsa yang maju dan bermoral seharusnya membayar hutang itu dengan Trias yang memuat tiga hal, yaitu; edukasi, irigasi dan emigrasi.

Kadang-kadang politik etis sering disebut politik paternalistik, yakni politik pemerintah kolonial yang ingin mengurus kepentingan anak negeri tanpa mengikutsertakan anak negeri itu sendiri. Namun bagi bangsa terjajah (baca Indonesia) politik etis hanyalah suatu dalih bangsa penjajah untuk melegalisasikan penjajahan mereka. Oleh karena itu, haluan politik etis lebih banyak slogannya daripada kenyataannya.

Terlepas dari kepentingan Belanda di balik penerapan politik etis, tetapi nampaknya dengan politik etis, rakyat Indonesia memperoleh perlakuan yang cukup baik. Dengan politik ini rakyat Indonesia dininabobokan, karena pada hakikatnya politik ibarat hadiah yang diberikan dengan tangan kanan dan mencabutnya kembali dengan tangan kiri.

Khusus dalam bidang pendidikan, pengembangan yang dilakukan pemerintah kolonial tidak didasarkan atas kebutuhan rakyat Indonesia, di mana tidak terdapat tempat-tempat penampungan (berupa lapangan kerja) para lulusan sekolah-sekolah yang dibentuk oleh Belanda sehingga menimbulkan kekecewaan di kalangan rakyat Indonesia.

Sejak awal abad XX diperkenalkan sistem sekolah desa (volksshool) yang pendiriannya tergantung pada kemampuan masyarakat desa setempat dan subsidi serta bimbingan pemerintah. Untuk keperluan anak-anak dari kelas atasan didirikan Hollandsch Inlandsche School (HIS). Pada sekolah ini secara bertahap dipakai bahasa Belanda sebagai 
bahasa pengantar. Setelah menyelesaikan pelajaran selama tujuh tahun, siswa yang dikategorikan pintar dan orang tuanya mampu secara ekonomi, maka dilanjukan ke sekolah Meer Uitgebreid Lager Onderwijs (MULO), sekolah lanjutan pertama, dan dari sini bisa dilanjutkan ke Algemeene Middelbare School (AMS).

Dalam perkembangan berikutnya apabila ada kesempatan ditambah dengan kemampuan intelektual dan ekonomi yang baik, maka bisa melanjutkan ke pendidikan tinggi.

Hal menarik lainnya yang berkaitan dengan kebijakan pemerintah kolonial Belanda melalui implementasi politik etis di Indonesia adalah mendirikan Sekolah Desa yang bertujuan untuk memberikan pengetahuan membaca, menulis dan berhitung kepada orang-orang desa. Program ini merupakan satu langkah maju untuk memberantas buta huruf bagi masyarakat desa.

Pada tahun 1909 - 1910 masalah pendidikan bagi masyarakat Indonesia kembali mendapat kritik dari seorang ahli tanah jajahan yang bernama H. Colijn. Kritikan Colijn terhadap Sekolah Rakyat Kelas Satu yang didirikan pada tahun 1914. Colijn mengkritik struktur pendidikan di Indonesia dengan memberikan peringatan bahwa sifat kegiatan dan kewajiban yang demikian penting bagi orang Barat selalu tidak terdapat pada orang-orang Indonesia yang telah merasakan pendidikan Barat.

Tujuan dari semua pendidikan sebagaimana digabarkan di dalam politik etis adalah untuk membebaskan orang Indonesia menjalankan peranan yang lebih aktif dalam masa depan politik, ekonomi dan sosial orang Indonesia sendiri. Kekuasaan politik, sebagai tambahan pada prosedur desentralisasi juga diperluas pada birokrasi di mana terdapat upaya "Pengindonesiaan" korps administrasi.

Perkembangan Pendidikan Formal Di Kepulauan Sangihe Akhir Abad XIX dan Awal Abad XX

Sementara itu genderang Pergerakan Nasional yang telah berkumandang di Pulau Jawa dengan bangkitnya cita-cita (ide) dan semangat nasionalisme Indonesia yang ditandai oleh berdirinya organisasiorganisasi Pergerakan Nasional seperti Budi Utomo (1908), Sarikat Dagang Islam (SDI) tahun 1909 (1909/11), Serikat Islam (1911), Indische Partij (1912), dan lainlain ternyata telah turut pula mengimbasi ataupun mempengaruhi alam pendidikan di daerah Sangihe Talaud ini pada masa itu. Hal ini terbukti antara lain dari mulai diserahkannya sekolah Gubernemen yang didirikan oleh pemerintah Hindia Belanda kepada seluruh sekolah Zending pada sekitar tahun 1915 sehingga sekolah Gubernemen pada waktu itu sudah terbagi dua, yaitu kelas I sampai dengan kelas III diserahkan dalam urusan/ pengawasan Sangihe en Talaud Commitee dan dinamakan Sekolah Rendah Zending. Sedangkan yang sisa, yaitu kelas V dan kelas VI tetap dalam pengawasan pemerintah Hindia Belanda dan disebut : Sekolah Gubernemen Kelas II. Sekolah ini nanti diserahkan sepenuhnya oleh pemerintah Hindia Belanda kepada Sangihe en Talaud Commite sekitar tahun 1935 sehingga sekolah Zending pun berubah dari 3 kelas menjadi 5 kelas.

Sedangkan Sangihe en Talaud Commite (dari golongan Kristen) mendirikan banyak sekolah dasar yang terdampar hampir di semua kampung di Kepulauan Sangihe Talaud antara lain HIS di Tahuna pada tahun 1919 dan HIS di Ulu Siau pada tahun 1930, sedangkan 
Kweekschool di Kaluwatu sudah didirikan sejak tahun 1907.

Pada akhir tahun 1932 didirikanlah sebuah Madrasah di kota Tahuna (kampung Tidore) dengan ketuanya ialah Badrun Suleman seorang tua yang dibuang Belanda di Tidore (Tahuna) dan wakil ketua ialah Marjan Karmela yang kemudian dihukum oleh Jepang sebagai guru satu-satunya pada waktu itu ialah Hassan Bakhmid.

Bersamaan dengan didirikannya madrasah tersebut di atas, yaitu sekitar 1932, umat Katolik di Manganitu pun mendirikan sebuah sekolah rendah bertiga kelas. Di sekolah ini diterima muridmurid untuk kelas I (murid baru), dan untuk kelas II-III diterima murid-murid yang telah berhenti bersekolah di sekolah Zending yang masih dalam batas umur bersekolah.

Demikian pada tahun 1933 oleh Missi Katolik dari sekolah tersebut dikirimlah enam orang murid ke RK Normaalschool di Tomohon. Pada tahun 1937 dari keenam orang itu, empat orang telah berhasil lulus ujian akhir sehingga untuk Sekolah Rendah RK di Manganitu diberi tambahan dua orang tenaga guru dan yang lain seorang dikirim ke Sekolah Rendah RK di Talaud (Mangaran) dan yang seorang lagi ke SR-RK di Kahakitang.

Oleh tambahan dua orang tenaga guru ini maka SR-RK Manganitu berkembang dari tiga kelas menjadi lima kelas. Di sekolah ini diterima muridmurid dari seluruh golongan agama yang ada di Manganitu pada waktu itu yaitu anak-anak yang beragama Islam, Katolik dan Protestan.

Selama masa kekuasaan VOC sampai kira-kira tahun 1800, perkembangan agama maupun pendidikan di daerah
Sangihe Talaud dapat dikatakan terlantar oleh karena tidak adanya suatu badan keagamaan yang langsung menangani selain VOC sebagai badan dagang. Juga belum ada pendetapendeta apalagi guru yang menetap di daerah ini, selain kunjungan sewaktu-waktu secara insidental oleh beberapa pendeta sebagaimana telah dikemukakan terdahulu. Kelak sesudah VOC dibubarkan pada akhir 1799 lalu mulailah pemerintahan Hindia Belanda (1800), barulah kemudian dikirim lebih banyak pendeta ke daerah Sangihe Talaud sebagaimana yang secara singkat dan berturut-turut telah diutarakan di depan.

Pada tahun 1817 pendeta J.Kam dari Ambon datang mengunjungi pulaupulau di Sangihe Talaud, antaranya pulau Tagulandang, Siau dan meneruskan perjalanannya ke Pulau Sangihe Besar. Pada tahun 1821 atas permintaan pendeta tersebut. Jungmickel dari Ternate datang mengunjungi daerah ini dan kemudian disusul oleh kunjungan van der Dessen pada tahun 1832 Semua kunjungan tersebut di atas, tidak membawa hasil yang diharapkan dari jemaat-jemaat di Sangihe Talaud. Karena itu pada tahun 1837 pendeta Zending Hovelear dari Ternate mengusulkan kepada N.Z.G. (Nederlands Zendings Genootschap) supaya di Sangihe Talaud dapat didirikan suatu Institut untuk pulau-pulau ini, tetapi tidak mendapat tanggapan dari N.Z.G.

Tujuh belas tahun kemudian pendeta Budding mengunjungi pulau-pulau ini selama sembilan hari. Tahun 1855 NZG mengutus pendeta Zending Van der Velde van Cappelen dari Minahasa untuk mengetahui pekerjaan apa yang dapat dibuat di bidang pendidikan. Pendeta inilah yang menulis suatu laporan panjang kepada NZG dan mendesak kepada NZG supaya mengutus dua pendeta Zending 
ke Sangihe Talaud. Sementara usul itu dipertimbangkan oleh NZG, pendeta Heldrin dari Hemmon (Belanda) yang mempunyai perhatian terhadap pekerjaan pekabaran Injil di kepulauan Sangihe Talaud, meminta kepada pemerintah untuk membantu membiayai tenagatenaga zending yang akan diutus ke Sangihe Talaud.

Rombongan utusan yang pertama terdiri atas empat orang yaitu : Schroder, Steller, Keling dan Grohe yang berangkat sesudah mereka diteguhkan, yaitu pada tahun 1855 melalui Betawi untuk berurusan dengan pemerintah Belanda di Betawi, namun ternyata urusan ini cukup memakan waktu karena pendidikan dasar mereka sangat kurang. Kemudian pada bulan Oktober 1856, keempat pekabar Injil di atas diperkenankan bertugas di Sangihe Talaud. Hal ini terjadi setelah pengurus Protestantsche Kerk menguji mereka dan memberi ijazah yang berkualifikasi sebagai pendetaa (Gembala Jemaat) sekaligus sebagai guru untuk para jemaat Protestan di Sangihe Talaud.

Menurut laporan Ds. v.d. Velde van Capellen (1855) di kepulauan Sangihe Talaud terdapat 24 sekolah yang tersebar di enam kerajaan yaitu :

1. Di Kerajaan Tagulandang, tiga buah masing-masing di Tagulandang, Hassi dan Minanga

2. Di Kerajaan Siau, sembilan buah antara lain di Ondong, Ulu, Sawang, Makalehi, Kahakitang, Para

3. Di Kerajaan Manganitu, dua buah yaitu di Manganitu dan di Lapango

4. Di Kerajaan Tahuna, tiga buah yaitu di Tahuna, Kolongan dan Sawang

5. Di Kerajaan Kendahe (Kendhar), satu buah yaitu di Kendahe
6. Di Kerajaan Tabukan, enam buah yaitu di Tabukan, Tariang, Kuma, Kulur, Manalu dan Salurang.

Umumnya sekolah-sekolah yang ditangani oleh Zending termasuk sekolah yang dinamakan Volkschool (sekolah rakyat) dengan jangka waktu pendidikan selama tiga tahun yaitu kelas 1,2, dan 3 dengan bahasa Melayu sebagai bahasa pengantar. Di samping itu pemerintah kolonial juga membuka sekolah-sekolah yang disebut sekolah Gubernemen (Sekolah Pemerintah) yang umumnya merupakan lanjutan dari Volkschool dan disebut Vervolgschool dengan jangka waktu pendidikan selama dua tahun. Selain itu pemerintah Belanda mendirikan pula HIS (Hollands Indlanse School) khusus untuk anak-anak bangsa Belanda dan orang Indonesia yang mampu ataupun yang dikatakan berdarah Belanda. Di samping itu dikenal pula sejenis sekolah yang dikatakan Schakelschool dengan ijazah tersendiri dan merupakan perantara bila seorang tamatan Vervolgschool mau mengambil ijazah sekolah yang berbahasa Belanda. Mengenai HIS, sekolah ini mempergunakan bahasa Belanda sebagai bahasa pengantar dengan masa pendidikan selama tujuh tahun (kelas 1 s/d kelas 7).

Kemudian atas permintaan menteri Daerah Jajahan pada akhir tahun 1857 berangkat pula rombongan kedua untuk pulau-pulau Talaud terdiri atas lima orang, yaitu Van Essen, Gunther, Richter (dari Belanda) dan Tauffmaan, Fischer (dari Jerman).

Pekerjaan mereka diinspeksi/diawasi oleh Kerkbestuur dari Manado. Tetapi mereka bukan tenaga Kerkbestuur dan bukan pendeta Zending. Pemerintah Belanda sebagai pewaris VOC bersedia untuk berusaha agar kebutuhan- 
kebutuhan keagamaan penduduk di Sangihe Talaud dapat dipenuhi dan kedudukan pekerja-pekerja di situ dapat diperbaiki. Untuk itu maka pada tahun 1891 didirikanlah Sangihe en Talaud Comitee inilah yang diserahi tanggung jawab penuh untuk pekerjaan keagamaan di Sangihe Talaud dan mendapat subsidi dari pemerintah.

Pada tahun 1854 Ds Budding dalam waktu sembilan hari saja telah membaptis 1658 orang di Sangihe. Menurut laporan Ds. S.D. Van der Velde van Capellen pada 5 Oktober 1855 ketika terus di Tagulandang ia merasa terharu ketika mendengar anak-anak sekolah dan orangorang tua menyanyikan lagu "Seakan Rusa Berdahaga".

Di samping membaptis orang, pendeta-pendeta tersebut mendidik pula pembantu-pembantu mereka yang lebih dikenal dengan nama Penulong yang berarti penolong atau membantu. Mereka inilah yang kemudian dididik lebih kanjut menjadi sebagai Guru Jemat (Guru Jemaat) bahakan ada juga yang menjadi guru biasa disebut Kweekling yaitu orang biasa yang kemudian dididik untuk menjadi guru dapat mengajar orang lain untuk mengenal huruf sampai dapat membaca. Ada juga yang disebut Verwilher yaitu orang-orang yang sudah dididik dan dilatih sebagai magang guru dan sudah berpengalaman setelah melalui suatu ujian yang disebut Help Onderwijs atau ujian sebagai pengajar pembantu (guru bantu).

Di samping itu ada juga tenagatenaga guru yang didatangkan dari daerah lain terutama dari minahasa seperti antara lain A.L. Lapian yang ditempatkan di Kendahe Tahuna, Perik ditempatkan di Manalu dan Sangihe ditempatkan di Kolongan. Juga ada putra-putri daerah ini (Sangihe Talaud) yang telah mengikuti pelajaran di daerah lain seperti antara lain Bapak Paul Usu, bekas tamatan Normaal School di Makasar (Ujung Pandang) dan Ibu Lantemona, bekas tamatan Normaal School di sasaran Tondano (Minahasa).

Sementara itu bahkan sebelumnya, Pemerintah Hindia Belanda juga sudah membuka sekolah-sekolah yang disebut Gubernemen (sekolah pemerintah/sekolah negeri) ataupun sekolah rakyat (S.R.). Namun orientasi dan tujuan pendidikan pada masa itu tidak lain adalah untuk kepentingan pemerintah penjajah (Belanda) sendiri serta tidak merata dan dirasakan oleh seluruh masyarakat. Faktor keturunan sangat menentukan untuk melanjutkan pendidikan ke tingkat yang lebih tinggi kalau sempat menempuh pendidikan sampai berijazah SD kelas III. Namun sejak 1830 di wilayah Kecamatan Tamako telah ada sebuah sekolah yakni sekolah Gubernemen dengan gurunya Doun Agustinus Makagiansar kakek dari Bapak Max Makagiansar. Lama kelamaan sekolah ini berkembang sehingga didirikanlah gedungnya yang dapat menampung lebih banyak murid. Pada tahun 1859 berdirilah sekolah Gubernemen (SR) Tamako yang sekarang ini telah dilebur (diganti namanya/menjadi Sekolah Dasar Negeri (SDN) I Tamako). Sekolah inilah yang merupakan sekolah tertua di Tamako.

Hampir bersamaan dengan waktu tersebut yakni sekitar tahun 1870 pemerintah Hindia Belanda telah membuka pula sebuah sekolah di Manganitu yang disebut sekolah Gubernemen kelas II yang berlima kelas. Sebagaimana telah diuraikan di muka, sejak saat itu terutama sesudah berdirinya Sangihe en Talaud Commite (1891, di daerah Sangihe Talaud, didirikanlah pula sekolah Zending, baik yang bertiga kelas 
maupun yang berenam kelas. Sekolahsekolah itu antara lain adalah :

1. Sekolah Rakyat (SR) Dagho pada tahun 1880

2. Sekolah Rakyat (SR) Nagha pada tahun 1880

3. Sekolah Rakyat (SR) Lawang pada tahun 1880

4. Sekolah Rakyat (SR) Lelle (Para) tahun 1887

5. Sekolah Rakyat (SR) Binala tahun 1890

6. Sekolah Rakyat (SR) Kalama tahun 1890

7. Sekolah Rakyat (SR) Kalinda tahun 1890

Sejalan dengan politik kolonial Pemerintah Hindia Belanda waktu itu yang menjalankan politik etis guna mendapatkaan tenaga-tenaga terampil ataupun terdidik untuk kepentingan pemerintahnya, maka di daerah Sangihe Talaud inipun pemerintah Belanda meneruskan pembukaan sekolah-sekolah Gubernemen (sekolah pemerintah) sebagaimana sebagian telah dikemukakan di atas. Sebagai kelanjutannya, pemerintah Belanda membuka pula sekolah-sekolah Gubernemen di beberapa tempat seperti Tagulandang, Ondong, Ulu-Siau, Tahuna, Tabukan Lama, Manganitu, Tamako, Kolongan, Kuma, Manalu, dan lain-lain.

Di samping sekolah-sekolah Gubernemen di atas, Sangihe en Talaud Commitee pun tak ketinggalan membuka sekolah-sekolah. Di setiap desa di mana ada jemaat yang cukup dibukalah sekolah sehingga hampir seluruh desa di daerah Kepulauan Sangihe Talaud, berdirilah sekolah-sekolah Zending, baik yang bertiga kelas maupun yang berlima kelas.
Sebagai contohdidaerah Tamako(sekarang kecamatan Tamako), di samping sekolahsekolah Zending yang telah disebutkan di atas (dibuka pada akhir abad ke-19), pada permulaan abad ke-20 berturut-turut dibuka pula sekolah-sekolah :

1. SR (Sekolah Rakyat) Apenglawo (Para) tahun 1909 ;

2. SR (Sekolah Rakyat) Lelipang (dibuka tahun 1912) ;

3. SR (Sekolah Rakyat) Bebu (dibuka tahun 1912) ;

4. SR (Sekolah Rakyat) Mahengetang (dibuka tahun 1918) ;

5. SR (Sekolah Rakyat) Dalako, dibuka pada tahun 1959 (sesudah kemerdekaan Indonesia).

Karena semakin banyaknya jumlah sekolah dibuka, maka sudah jelas faktor kekurangan guru adalah menjadi salah satu hambatan ataupun masalah yang harus segera dicarikan jalan keluarnya. Untuk itu maka usaha-usaha yang ditempuh pada saat itu antara lain : (1) Zending mengutus putra-putri daerah Sangihe Talaud ke sekolah guru (Normaal School) di Kuranga (Tomohon) dan ke seminari Depok di Jawa: (2) Mengadakan ujian bagi tamatan Vervolgschool, mereka yang lulus dalam ujian diangkat sebagai guru (Verpleger) dan dianggap sederajat dengan VO (Volks Onderwijs); (3) Membuka sekolah guru (Kweekschool) di Kaluwatu Kecamatan Manganitu Selatan pada tahun 1907 ; (4) Membuka sekolah guru 2 tahun (VO) di Ulu-Siau pada tahun 1938.

S ebagai tambahan untuk melengkapi keadaan pendidikan di daerah Sangihe Talaud pada akhir abad ke-19 (sebelum abad ke-20), maka dapat dicatat bahwa 
sekolah-sekolah Gubernemen yang telah didirikan oleh pemerintah Hindia Belanda sejak \pm 1830 di atas, makin lama makin berkembang sehingga lama pendidikannya pun berkembang pula dari 3 tahun atau 3 kelas (Volkschool) menjadi 5 tahun (Vervolgschool). Murid-murid tamatan Volkschool dapat melanjutkan pelajarannya ke Vervolgschool. Dan dari tamatan-tamatan Vervolgschol ini dapat pula melanjutkan pelajarannya ke sekolah lanjutan atau Muloschool setelah melalui penyaringan yang ketat di mana faktor keturunan turut juga menentukan. Karena persyaratan yang begitu ketat inilah, di samping sekolah MULO atau memang sekolah lanjutan ini memang tidak ada di daerah Sangihe Talaud pada waktu itu, maka anak-anak rakyat jelata terpaksa tidak dapat melanjutkan pelajarannya lagi sehingga anak-anak tersebut akhirnya kembali ke desa menjadi warga desa dengan bekal pengetahuan SD 3 tahun atau SD 5 tahun.

Sebagian lagi anak-anak yang kurang berhasil baik, yakni mereka yang tidak sempat menduduki bangku sekolah dan mengecap pendidikan selama masa kanak-kanak mereka, terpaksa harus puas dengan menerima pendidikan yang diberikan oleh ibu, bapak atau orang tua di dalam keluarga.

Dengan Demikian keadaan pendidikan di daerah Sangihe Talaud, baik pendidikan formal maupun pendidikan informal pada akhir abad ke19 dan permulaan abad ke-20. Jelas dapat dilihat bahwa pendidikan yang ada pada waktu itu masih terbatas pada pendidikan Sekolah Dasar, khususnya pendidikan sekolah dasar pemerintah Hindia Belanda baik berupa sekolah kelas satu, sekolah kelas dua maupun Volkschool dan Vervolgschool.

\section{PENUTUP}

Dari hasil penelitian ini maka dapat disimpulkan bahwa khusus dalam bidang pendidikan, pengembangan yang dilakukan pemerintah kolonial tidak didasarkan atas kebutuhan rakyat Indonesia, di mana tidak terdapat tempat-tempat penampungan para lulusan sekolah-sekolah yang dibentuk oleh Belanda sehingga menimbulkan kekecewaan di kalangan rakyat Indonesia. Sejak awal abad XX diperkenalkan sistem sekolah desa (volkschool) yang pendiriannya tergantung pada kemampuan masyarakat desa setempat dan subsidi serta bimbingan pemerintah. Untuk keperluan anak-anak dari kelas atasan didirikan Hollandsch Inlandsche School (HIS). Perkembangan pendidikan formal di Kepulauan Sangihe dalam kurun waktu akhir abad XIX dan awal abad XX dapat dilihat seperti halnya perkembangan pendidikan di daerah lain di Indonesia. Khusus untuk kepulauan Sangihe. Tujuan mendirikan lembaga pendidikan oleh Belanda terutama bukan untuk kepentingan orang Indonesia pada umumnya terlebih khusus orang Sangihe, tetapi sesungguhnya adalah untuk kepentingan mereka, yaitu mengisi jabatan rendah dalam pemerintahan dan untuk mengisi tenaga pada perusahaan swasta Belanda. Sebagai tambahan untuk melengkapi keadaan pendidikan di daerah Sangihe Talaud pada akhir abad ke-19 (sebelum abad ke-20), maka dapat dicatat bahwa sekolah-sekolah Gubernemen yang telah didirikan oleh pemerintah Hindia Belanda sejak \pm 1830 di atas, makin lama makin berkembang sehingga lama pendidikannya pun berkembang pula dari 3 tahun atau 3 kelas (Volkschool) menjadi 5 tahun (Vervolgschool). 
Sepenggal uraian masa lalu ini akan memberikan harapan kepada setiap manusia Indonesia untuk berupaya memperbaiki dirinya melalui dunia pendidikan. Oleh karena itu melalui karya sederhana ini disarankan agar ke depan seyogyanya program-program pendidikan yang direncanakan dan di laksanakan di Indonesia, hendaknya lebih berorientasi pada kepentingan masyarakat dan bukan kepentingan politik dari pembuat dan pengambil keputusan, sehingga rakyat tidak dibuat kecewa serta terus menerus menangis lagi.

Seruan ini tidak berlebihan apabila dapat dijadikan acuan dalam proses perencanaan dan pelaksanaan program pembangunan pendidikan di Indonesia. Jika tidak, maka apa yang dilaksanakan bukan lebih mensejahterakan rakyat, tetapi menciptakan perasaan kurang puas dan bahkan tidak percaya kepada pemerintah. Namun demikian ada sedikit harapan bahwa tidak ada perilaku manusia yang tidak dapat diubah, karena itu perilaku pemerintahan kolonial Belanda di masa lalu dalam dunia pendidikan Indonesia akan berdampak pada upaya perbaikan di masa-masa yang akan datang. Perubahan itu dapat terjadi apabila kita mampu menghormati dan menghargai hak-hak masyarakat dalam dunia pendidikan.

\section{DAFTAR PUSTAKA}

Brilman D, (1986). Wilayah-wilayah Zending Kita, Zending di Kepulauan Sangi dan Talaud.Yayasan Frater Andreas. Manado

Kartodirdjo, Sartono, (1992). Pengantar Sejarah Indonesia Baru : 1500 - 1900 Dari Emporium sampai Imperium Jilid 1. Jakarta : PT Gramedia Pustaka Utama

Nasution, S, (1995). Sejarah Pendidikan Indonesia. Jakarta: Bumi Aksara
Samodara, D, (1980). Perkembangan Pendidikan di Manganitu, SULUT Manganitu

Walukow, Alfian, (2007). Periodisasi Sejarah, Kebudayaan Sangihe, Kebudayaan Philiphines Tua. Pananaru SULUT 